\title{
Assessing visitor satisfaction with a pioneering agritourism project: vegetable tourism in the Parc Agrari del Baix Llobregat (Barcelona)
}

\author{
Valerià Paül Carril* \\ Universidade de Santiago de Compostela (España) \\ Noelia Araújo Vila** Pablo de Carlos Villamarín*** \\ Universidade de Vigo (España)
}

\begin{abstract}
Among the major changes that have occurred in the tourist sector in recent years, of particular note has been the constant emergence of new products that seek to satisfy the needs of tourists demanding new kinds of consumer experiences. A good example of this is agritourism, in which the tourist participates in the typical activities of a working farm. This study focuses on a recent variant of this type of tourism, known as vegetable tourism (or holeriturismo in Spanish). Specifically, an assessment is undertaken of a pioneering project in Spain on an agricultural park: the Parc Agrari del Baix Llobregat (Barcelona). Based on the information obtained from a survey conducted in the Park itself, the degree of visitor satisfaction with the various activities they experience is analysed. Using non-parametric statistical methods, the study seeks to determine whether the visitors' socio-demographic profile and their knowledge of the concept of vegetable tourism have a significant impact on their assessments.
\end{abstract}

Keywords: agritourism, vegetable tourism, Parc Agrari del Baix Llobregat, non-parametric statistical methods, satisfaction.

La evaluación de la satisfacción del visitante con un proyecto agroturístico pionero: el turismo de verduras en el Parc Agrari del Baix Llobregat (Barcelona)

Resumen: Entre los principales cambios que se han producido en el sector turístico en los últimos años, de mención especial ha sido la aparición constante de nuevos productos que buscan satisfacer las necesidades de los turistas más exigentes. Un buen ejemplo de ello es el agroturismo, en el que el turista participa en las actividades típicas de una explotación agraria. Este estudio se centra en una variante reciente de este tipo de turismo, conocida como holeriturismo. En concreto, el análisis se lleva a cabo en un proyecto pionero en España en un parque agrario: el Parc Agrari del Baix Llobregat (Barcelona). Con base a la información obtenida de una encuesta realizada en el propio Parqu, se analiza el grado de satisfacción de los visitantes con las diversas actividades que experimentan. A través del uso de métodos estadísticos no paramétricos, el estudio busca determinar si el perfil sociodemográfico de los visitantes, y su conocimiento del concepto de turismo de verduras tienen un impacto significativo en sus valoraciones.

Palabras Clave: agroturismo, holeriturismo, Parc Agrari del Baix Llobregat, métodos estadísticos no paramétricos, satisfacción.

* Universidad de Santiago de Compostela (España); E-mail: v.paul.carril@usc.es

** Doctora en Dirección y Planificación del Turismo. Investigadora y profesora invitada del Dpto. de Organización de Empresas y Marketing (Universidad de Vigo); E-mail: naraujo@uvigo.es

** Universidad de Vigo (España); E-mail: pdecarlo@uvigo.es 


\section{Introduction}

Peri-urban agricultural spaces have gradually been converted into places for the practice of a range of leisure, recreational and tourist activities. Thus, the farmers' traditional tasks are today being undertaken alongside other activities such as hiking and running (Bryant et al., 1982; Bryant and Johnston, 1992). The direct result of these changes has been the emergence in these spaces of the activities of agritourism, which have evolved considerably so that today they encompass the full participation of tourists in the tasks of a working farm, including the tasting of the products that are harvested and produced on it. This combination of leisure activities and agriculture does not require any particular investment, since it is based on an existing infrastructure: that of agriculture and the land. Furthermore, agritourism contributes to the conservation of an area's farming, inasmuch as it "consumes" the products of farming as well as its places of production (Paül and Araújo, 2012; Michelin et al., 2007).

Clearly, a key element here is the management of the public use of these peri-urban parks (Arnberger and Brandenburg, 2007). The leisure and recreational activities that were first to emerge at the urban edge were primarily walking, cycling and running. However, in more recent times, there has been a growing awareness of the need to promote more original initiatives to develop tourism and the public use of peri-urban agricultural parks, so that tourists might become more familiar with the agricultural nature of these spaces. It is this need that the agritourism sector has responded to, although in general the sector has been associated with quintessentially rural areas and not peri-urban areas (Paül and Araújo, 2012). In the Mediterranean region, peri-urban agriculture corresponds largely to its market gardens and orchards (Meeus, 1995), which means that agritourism should be based around horticultural crops, i.e. fruit and vegetables. From here we derive the Spanish term used in the Mediterranean of holeriturismo, from the Latin HOLUS meaning vegetable + tourism, that is, vegetable tourism, and which basically involves the exploration of the region's market gardens and orchards. According to unpublished documents of the Parc Agrari del Baix Llobregat (Baix Llobregat Agricultural Park) - in which this variety of tourism has been a pioneer project - this variant of agritourism can be defined as the tourism that takes as its point of reference and main element of interest market garden vegetables and, by extension, fruit and all their associated qualities of flavour, colour and texture, etc., as well as the traditional practices employed by the farmers in their cultivation. In short, the aim is to disseminate a better understanding of the region's market gardens.

The large body of literature that has concerned itself with agritourism (Hoyland, 1982; Frater, 1983; Murphy, 1985; Pearce, 1990; Bowen et al., 1991; Hilchey, 1993; Viñals, 1999; Mesa, 2000; Przezbórska, 2003; Hernando et al., 2003; Phillip et al., 2010) has tended to focus its attention on what the sector can offer. Moreover, the few studies examining demand in the sector have tended to examine tourism in rural areas and not specifically agritourism (Kastenhold et al., 1999; Frochot, 2005; Molera and Albaladejo, 2007; Park and Yoon, 2009; Oh and Schuett, 2010). Drawing on survey information, this literature identifies different segments of tourists in relation to the benefits sought and determines their profiles as a function of their socio-demographic characteristics or patterns of behaviour while on holiday. However, from a review of this literature it quickly becomes apparent that little is known about the profile of the consumers of agritourism or their opinions about this type of tourism, essential information to provide the necessary feedback for those that promote this sector. This paper seeks to fill this gap.

Based on the fundamental principle of marketing according to which all products have to satisfy the needs, desires and wants of the consumer, the concept of market segmentation emerges. This means "viewing a heterogeneous market as a number of smaller homogeneous markets, in response to differing preferences, attributable to the desires of customers for more precise satisfactions of their varying wants" (Smith, 1956, p.6). This strategic choice has enabled firms in many sectors to successfully tackle constant changes in consumer behaviour.

A fundamental concern when undertaking such segmentation is the definition of the variables on which it will be based. Frank et al. (1972) proposed a classification of these variables that remains an essential reference in the field, as is evidenced by a number of recent studies including Li et al. (2011) and Radder and Han (2011). This classification identifies two levels, that of generality (general and brand specific) and that of objectivity (observable and unobservable), as shown in Table 1. 
Table 1: Model of variables that influence market segmentation

\begin{tabular}{|c|c|c|}
\hline & General & Specific \\
\hline Observable & $\begin{array}{l}\text { - Demographic: gender, age, } \\
\text { marital status... } \\
\text { - Socio-economic: income, } \\
\text { occupation, education... } \\
\text { - Geographic: nationality, región, } \\
\text { habitat... }\end{array}$ & $\begin{array}{l}\text { - Usage frequency and situation } \\
\text { - Brand and store loyalty } \\
\text { - State of adoption } \\
\text { - Type and place of purchase }\end{array}$ \\
\hline Unobservable & $\begin{array}{l}\text { - Personality traits } \\
\text { - Personal values } \\
\text { - Lifestyle }\end{array}$ & $\begin{array}{l}\text { - Perceptions } \\
\text { - Expectations } \\
\text { - Preferences } \\
\text { - Attitudes }\end{array}$ \\
\hline
\end{tabular}

Source: own elaboration based on Frank et al. (1972)

According to the literature, segmentation analysis begins by examining the variables (objective and general) included in the northwest quadrant, or more specifically those that define the socio-demographic profile of the consumer. Indeed, a central concern of this paper, which seeks to fill gap in the literature on agritourism, is the delimitation of the socio-demographic profile of the tourist or visitor who participates in the activities associated with this type of tourism. The analysis also takes into account other segmentation variables (specific and subjective) that lie in the southeast quadrant of the proposed model, that is, the degree of knowledge that tourists have of the agritourism product being examined. Unsurprisingly, there is considerable consensus to the effect that consumer familiarity with a particular product category influences the assessments consumers make of novel versions of that product (Alba and Hutchinson, 1987; Zhou and Nakamoto, 2007). In short, by analysing whether different consumer groups make significantly different assessments, valuable information can be obtained that promoters can use to improve the design and subsequent acceptance of a product.

This paper examines the vegetable tourism initiative undertaken by the Parc Agrari del Baix Llobregat (Barcelona, Spain). Planned in 2008, it was launched as a pilot project in 2009, to determine the degree of acceptance by tourists and visitors as well as by the farmers of the area. Exploiting the park's typical resources, and in an attempt to link tourism to them, a range of activities are offered that make up an integrated tourism product:

- Visits to farms specializing in one particular crop, in order to learn more about the specific vegetable and the landscape in which it is grown and to hear the explanations of the farmer.

- Exhibitions dedicated to the specific vegetable in a specially designed interpretation centre.

- Product tasting/production workshops.

- Visits to restaurants in the area where dishes can be tasted using the vegetables grown in the park.

- This is the first agritourism experience designed by a peri-urban agricultural park in Spain, as well as being the only one to be exclusively known as a vegetable tourism project. The pioneering nature of the present case gives added interest to this research.

The remainder of the paper is organised as follows. In the next section the methodology employed is outlined, including details regarding the determination of the sample to be analysed. The results are then reported and discussed in the final concluding section.

\section{Analytical methodology and sample}

Based on the findings of a survey conducted in the Parc Agrari del Baix Llobregat, this section analyses visitor assessments of the route and its activities, and also considers the level of understanding that the interviewees professed to have of vegetable tourism and the way in which they actually defined the activity. Similarly, using non-parametric tests, the study seeks to determine whether these assessments, including visitor responses regarding how much they know about vegetable tourism and how they define it, differ significantly depending on the characteristics of the respondents' profiles. The aim is to provide information that can improve the design of vegetable tourism routes, taking into account the preferences and wishes of the target audience, and to highlight the extent to which it is important to explain to the visitors the activity they are taking part in. 
To record the respondents' level of satisfaction with the route and its activities, we used a Likert scale, as is usual in studies assessing the satisfaction of consumers or users of a product or service (Oliver, 1981; Dubé-Rioux, 1990; Oliver, 1999; Cronin et al., 2000; Vanhamme, 2000; Brady et al., 2001; Jun et al., 2001 and Van Dolen et al., 2004). Specifically, it is a five-point scale ( $1=$ strongly disagree, $2=$ disagree, $3=$ indifferent, $4=$ agree, $5=$ strongly agree), composed of eleven items related to different aspects of the route and its activities that might affect the assessment that visitors make of the product being offered to them (Table 2).

Table 2: Items used in evaluating visitor satisfaction with the route and its activities

\begin{tabular}{|c|l|}
\hline A & The number of activities programmed is sufficient. \\
\hline B & All the activities have been interesting. \\
\hline C & All the explanations have been enjoyable. \\
\hline D & I enjoyed the guided walk through the fields. \\
\hline E & I enjoyed the guided visit to the exhibition. \\
\hline F & I enjoyed tasting the artichokes. \\
\hline G & I enjoyed meeting the farmer. \\
\hline H & The activities lasted the right amount of time. \\
\hline I & I enjoyed the pacing and rhythm of the activities. \\
\hline J & The number of participants is correct. \\
\hline K & The attention provided by the staff is good. \\
\hline
\end{tabular}

The survey includes two additional questions that seek to determine the extent to which the interviewees are familiar with the concept of vegetable tourism and how they define it (Table 3). First, the interviewees were asked whether they knew what this type of tourism was. They were presented with four alternative responses, with which it was hoped to ascertain whether their taking part in the route had influenced their understanding of the idea underpinning the activity. Second, the respondents were allowed to choose between possible definitions of vegetable tourism: one that was correct ("Tourism aimed at discovering market gardens and orchards"); another that was basically acceptable ("Visits to a suburban farming area in the outskirts of a city"); and two that were incorrect ("Market gardening in the outskirts of a city" and "Suburban farming"). In this way, it was hoped to discover whether the knowledge supposedly held by the respondent about the activity corresponded to an accurate understanding of its actual meaning.

Table 3: Questions determining the level of understanding that the interviewees professed to have of vegetable tourism and the way in which they actually defined it.

\section{DO YOU KNOW WHAT VEGETABLE TOURISM IS?}

a) I've never heard of it before.

b) I'd never heard of it until I started the route, but now I know what it means because it has been explained to me.

c) I have heard of it, but I still do not know what it means.

d) I've been able to find out what it means for myself during or after finishing the route.

\section{HOW WOULD YOU DEFINE VEGETABLE TOURISM?}

a) Visits to a suburban farming area in the outskirts of a city.

b) Market gardening in the outskirts of a city.

c) Tourism aimed at discovering market gardens and orchards.

d) Suburban farming. 
The survey was administered in the months of February and March 2011 by personal interviews conducted with the visitors as they finished the specific vegetable tourism activity. In these months, the main product being shown on the route was the artichoke (known in Catalan as CarxofaPrat), which explains why some of the questions on the survey specifically mention this vegetable. The total number of interviews conducted was 655 , of which 313 were valid ( $47.8 \%$ response rate) (Table 4 ).

Table 4: Technical details defining the research

\begin{tabular}{|l|l|}
\hline Characteristics & Survey \\
\hline Population & Visitors of the Parc Agrari del Baix Llobregat \\
\hline Geographical area & Parc Agrari del Baix Llobregat \\
\hline Sample size & 313 valid surveys \\
\hline Sample error & $\pm 5.5 \%$ \\
\hline Confidence level & $95 \% \mathrm{Z}=1.96 \mathrm{p}=\mathrm{q}=0.5$ \\
\hline Sample design & Systematic random sampling \\
\hline Data collection method & Personal interview \\
\hline Field work conducted between: & $12 / 02 / 2011-20 / 03 / 2011$ \\
\hline
\end{tabular}

Five variables were considered when determining the profile of the interviewees: sex, age, level of education, occupation and monthly family income (Figure 1).

Figure 1: Socio-demographic profile of the interviewees $(N=313)$

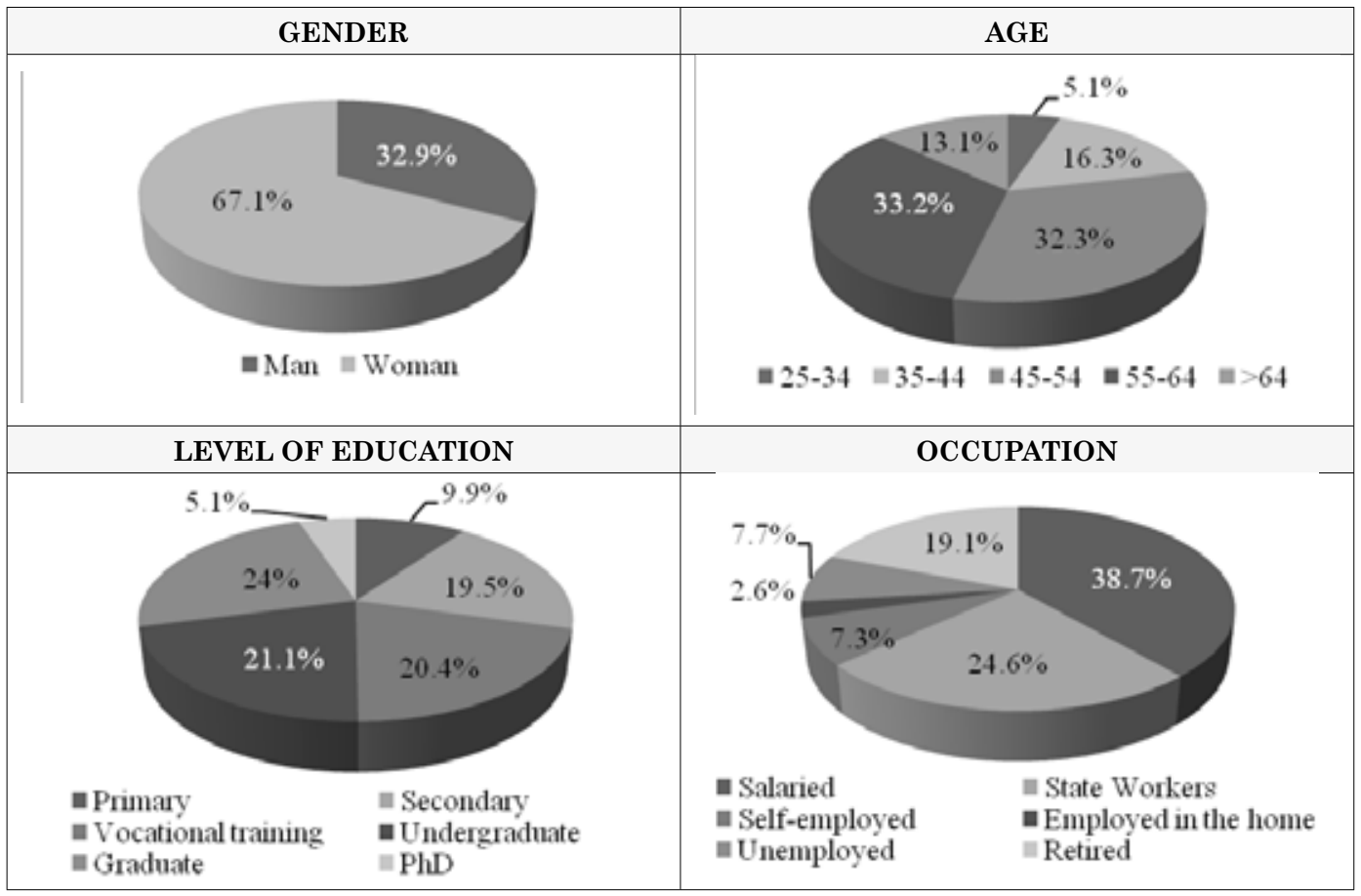




\section{MONTHLY FAMILY INCOME}

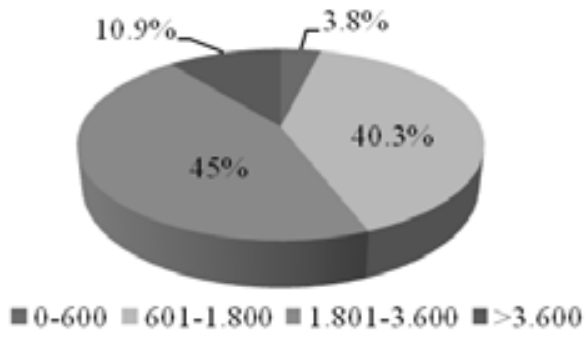

Source: own elaboration.

As can be seen, slightly more than two thirds of those interviewed are women. In addition, they are, on the whole, mature in age and well educated: only $21.4 \%$ of the respondents are under 45 years of age while $50.2 \%$ have a university degree. As for their occupation, almost four of every ten work as salaried employees (a quarter of these in the state sector), while a fifth are retired. Finally, $85.3 \%$ live in households with a monthly income of between 601 and 3,600 euros, distributed almost evenly between those with an income of between 601 and 1,800 euros, on the one hand, and those with an income of between 1,801 and 3,500 euros, on the other. In short, the average profile of the interviewees is that of a woman aged between 55 and 64 years of age, with a university degree, working as a salaried employee and whose monthly family income is between 1,801 and 3,600 euros, three to six times the minimum salary in Spain.

Given that the data are ordinal and do not follow a normal distribution, ${ }^{1}$ the non-parametric Kruskal-Wallis H-test and the Mann-Whitney U-test (Sheskin, 2007) were used to analyse whether the assessments of the route and its activities are significantly different depending on the profile of the interviewees and their responses regarding their knowledge and definition of vegetable tourism. When more than two samples are compared, the H-test fails to identify where the difference occurs, i.e., between which specific groups there is a systematic difference. It is, therefore, necessary to use the Mann-Whitney U-test. Thus, in the case of the sex variable, as there are only two options (i.e., two unrelated samples), the two tests yield the same result, and so the U-test is applied directly. For the rest of the variables, in which the number of options is greater than two (i.e., more than two unrelated samples), the H-test is applied first and, in those cases in which the test detects the presence of a significant relationship, the U-test is used to determine between which two specific groups it occurs. ${ }^{2}$ In short, the hypotheses tested are:

- Null Hypothesis $\left(\mathrm{H}_{0}\right)$ : no differences occur between any of the samples in terms of their responses to the questions posed. In other words, no systematically higher or lower assessments are recorded for any of the groups (samples) with respect to the others.

- Alternative Hypothesis $\left(\mathrm{H}_{\mathrm{A}}\right)$ : a difference is recorded between at least two of the samples in terms of their responses to the questions posed. In other words, systematically higher or lower appraisals are recorded in at least one of the groups (samples) with respect to the others.

\section{Analysis and results}

Below the results of the survey are analysed, beginning with those obtained in response to the questions regarding the visitors' knowledge and definition of vegetable tourism. As can be seen in Figure 2 , there is a clear majority $(70.6 \%)$ of respondents who believe they have understood what this type of tourism means, above all those that attribute this understanding to the explanations received while taking part on the route. By contrast, $22.4 \%$ claim never to have heard the concept before; whereas, only $7 \%$ recognize that they still do not understand what it means despite having heard people use the term. When defining this type of tourism, a clear majority $(77.9 \%)$ of those interviewed opted for the two accepted definitions and in fact the majority of those chose the correct one. It is worth stressing that, 
among those claiming to know what vegetable tourism is as a result of the explanations received on the route, $81.03 \%$ chose the two accepted definitions. An almost identical figure $(80.77 \%)$ was recorded by those who claimed to have found out the meaning for themselves during or after the route. By contrast, the percentage of correct responses fell ten points among those who claimed not to knowing the meaning of vegetable tourism. Therefore, in most cases the knowledge held by the respondent about the activity corresponded to an accurate understanding of its meaning.

Figure 2: Knowledge and definition of vegetable tourism among the interviewees

\begin{tabular}{|c|c|}
\hline $\begin{array}{l}\text { DO YOU KNOW WHAT VEGETABLE } \\
\text { TOURISM IS? }\end{array}$ & $\begin{array}{l}\text { HOW WOULD YOU DEFINE VEGETABLE } \\
\text { TOURISM? }\end{array}$ \\
\hline 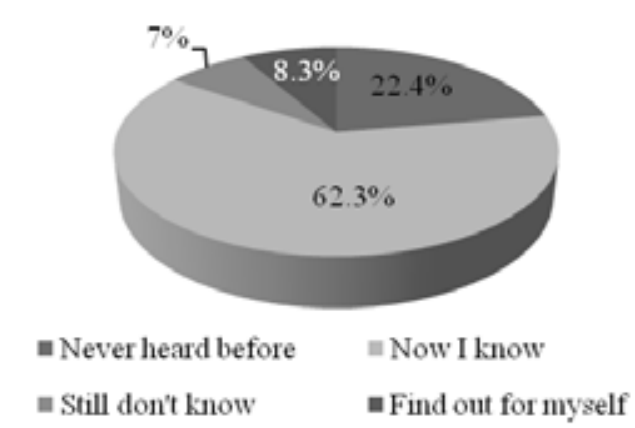 & $\begin{array}{l}\text { = Market gardening } \\
\text { = Suburban farming }\end{array}$ \\
\hline \multicolumn{2}{|c|}{$\begin{array}{l}\text { Note: Never heard before: I've never heard of it before; Now I know: I'd never heard of it until I started the } \\
\text { route, but now I know what it means because it has been explained to me; Still don't know: I have heard } \\
\text { of it, but I still do not know what it means; Find out for myself: I've been able to find out what it means } \\
\text { for myself during or after finishing the route. Visit: Visits to a suburban farming area in the outskirts of a } \\
\text { city; Market gardening: Market gardening in the outskirts of a city; Tourism: Tourism aimed at discovering } \\
\text { market gardens and orchards. }\end{array}$} \\
\hline
\end{tabular}

Source: own elaboration.

Given that our main interest in this section is the items that capture the level of user satisfaction with the route and its activities, we need to analyse the reliability of the scale. The value of Cronbach's Alpha coefficient (0.914) indicates that the scale has a high level of internal consistency. Moreover, the inter-item correlation matrix shows that the correlations between the different elements on the scale are all positive (no items are coded with an opposite sign to the others) and they can be considered acceptable, with a predominance of values between 0.4 and 0.58 , although item $\mathrm{F}$ ("I enjoyed tasting the artichokes") presents two correlations with values below 0.3 . However, this item presents a correlation with the scale formed by the remaining items (corrected index of homogeneity) greater than 0.40 (specifically, 0.464), which allows us to consider it consistent with the rest of the scale. Furthermore, were it to be eliminated, the value of the Alpha coefficient rises to just 0.915 . Therefore, the analysis confirms the validity and reliability of the survey used to measure the degree of satisfaction of the interviewees with the vegetable tourism activity undertaken.

In general, the opinions expressed by those interviewed regarding the route and its activities are very positive (Table 5). The mean values of the assessments are over 4 in all instances, fluctuating between 4.17 for item $H$ ("The activities lasted the right amount of time") and 4.78 for item $\mathrm{K}$ ("The attention provided by the staff is good"). In addition to item $\mathrm{K}$, four more items received an appraisal above the average for all the items (4.44): F ("I enjoyed tasting the artichokes"), G ("I enjoyed meeting the farmer"), B ("All the activities have been interesting") and D ("I enjoyed the guided walk through the fields"). The median, mode (in both cases the maximum value was predominant), the maximum and the minimum indicate the same result. In short, the route and its activities appear to have made a very favourable impression on the participants of the vegetable tourism experience. 
Table 5: Main descriptors of the assessments obtained for the eleven items on the survey

\begin{tabular}{|c|c|c|c|c|c|c|c|c|c|c|c|}
\hline ITEM & $\mathbf{A}$ & $\mathbf{B}$ & $\mathbf{C}$ & $\mathbf{D}$ & $\mathbf{E}$ & $\mathbf{F}$ & $\mathbf{G}$ & $\mathbf{H}$ & $\mathbf{I}$ & $\mathbf{J}$ & $\mathbf{K}$ \\
\hline $\mathbf{N}^{\mathbf{o}}$ answers & 313 & 313 & 313 & 313 & 313 & 313 & 313 & 313 & 313 & 313 & 313 \\
\hline Average & 4,32 & 4,48 & 4,40 & 4,46 & 4,26 & 4,68 & 4,63 & 4,17 & 4,29 & 4,38 & 4,78 \\
\hline Median & 4 & 5 & 5 & 5 & 4 & 5 & 5 & 4 & 4 & 5 & 5 \\
\hline Mode & 4 & 5 & 5 & 5 & 5 & 5 & 5 & 5 & 5 & 5 & 5 \\
\hline Minimun & 1 & 2 & 1 & 1 & 1 & 1 & 2 & 1 & 1 & 2 & 2 \\
\hline Maximun & 5 & 5 & 5 & 5 & 5 & 5 & 5 & 5 & 5 & 5 & 5 \\
\hline
\end{tabular}

Note: You can see the meaning of each item in Table 2.

Source: own elaboration.

Having presented the main findings from the responses to the survey, we next analyse whether the appraisals of the route and its activities differ significantly according to the sex, age, level of education, occupation and the family income of the interviewees, as well as according to the declared knowledge and real knowledge of the meaning of vegetable tourism. Below, the most important results are shown for those cases in which statistically significant differences were observed between two groups when applying the Mann-Whitney U-test (Table 6).

Table 6: Statistics corresponding to significant cases obtained when applying the Mann-Whitney U-test

\begin{tabular}{|c|c|c|c|c|c|c|c|c|c|}
\hline ITEM & GROUPS & $\mathbf{N}$ & $\rho$ & MIDRANGE & ITEM & GROUPS & $\mathbf{N}$ & $\rho$ & MIDRANGE \\
\hline \multirow[b]{2}{*}{ B } & Man & 103 & \multirow{2}{*}{$\begin{array}{l}0,0196 \\
(0,05)\end{array}$} & 142,03 & \multirow[b]{2}{*}{$\mathbf{E}$} & $\begin{array}{c}\text { Self- } \\
\text {-employed }\end{array}$ & 23 & \multirow{2}{*}{$\begin{array}{l}0,0012 \\
(0,003)\end{array}$} & 13,26 \\
\hline & Woman & 210 & & 164,34 & & $\begin{array}{c}\text { Employed } \\
\text { in the } \\
\text { home }\end{array}$ & 8 & & 23,88 \\
\hline \multirow[t]{2}{*}{ D } & Man & 103 & \multirow{2}{*}{$\begin{array}{l}0,0444 \\
(0,05)\end{array}$} & 143,99 & \multirow{2}{*}{$\mathbf{E}$} & $\begin{array}{c}\text { Self- } \\
\text {-employed }\end{array}$ & 23 & \multirow{2}{*}{$\begin{array}{l}0,0018 \\
(0,003)\end{array}$} & 29,98 \\
\hline & Woman & 210 & & 163,38 & & Retired & 60 & & 46,61 \\
\hline \multirow{2}{*}{$\mathbf{E}$} & Man & 103 & \multirow{2}{*}{$\begin{array}{l}0,0178 \\
(0,05)\end{array}$} & 141,13 & \multirow{2}{*}{$\mathbf{F}$} & $0-600$ & 12 & \multirow{2}{*}{$\begin{array}{l}0,0014 \\
(0,008)\end{array}$} & 43,42 \\
\hline & Woman & 210 & & 164,79 & & $601-1800$ & 126 & & 71,98 \\
\hline \multirow{2}{*}{$\mathbf{F}$} & Man & 103 & \multirow{2}{*}{$\begin{array}{l}0,0238 \\
(0,05)\end{array}$} & 144,56 & \multirow{2}{*}{ C } & $601-1800$ & 126 & \multirow{2}{*}{$\begin{array}{l}0,0023 \\
(0,008)\end{array}$} & 85,60 \\
\hline & Woman & 210 & & 163,10 & & $>3600$ & 34 & & 61,62 \\
\hline \multirow{2}{*}{$\mathbf{G}$} & Man & 103 & \multirow{2}{*}{$\begin{array}{l}0,0091 \\
(0,05)\end{array}$} & 141,93 & \multirow{2}{*}{ I } & $601-1800$ & 126 & \multirow{2}{*}{$\begin{array}{l}0,0011 \\
(0,008)\end{array}$} & 86,12 \\
\hline & Woman & 210 & & 164,39 & & $>3600$ & 34 & & 59,69 \\
\hline \multirow{2}{*}{$\mathbf{J}$} & Man & 103 & \multirow{2}{*}{$\begin{array}{l}0,0024 \\
(0,05)\end{array}$} & 137,09 & \multirow{2}{*}{$\mathbf{J}$} & $601-1800$ & 126 & \multirow{2}{*}{$\begin{array}{l}0,0031 \\
(0,008)\end{array}$} & 85,58 \\
\hline & Woman & 210 & & 166,76 & & $>3600$ & 34 & & 61,68 \\
\hline \multirow{2}{*}{ D } & Primary & 31 & \multirow{2}{*}{$\begin{array}{l}0,0026 \\
(0,003)\end{array}$} & 27,66 & \multirow{2}{*}{ B } & $\begin{array}{l}\text { Now I } \\
\text { Know }\end{array}$ & 195 & \multirow{2}{*}{$\begin{array}{l}0,0046 \\
(0,008)\end{array}$} & 112,55 \\
\hline & PhD & 16 & & 16,91 & & $\begin{array}{l}\text { Still don't } \\
\text { Know }\end{array}$ & 22 & & 77,55 \\
\hline
\end{tabular}




\begin{tabular}{|c|c|c|c|c|c|c|c|c|c|}
\hline ITEM & GROUPS & $\mathbf{N}$ & $\rho$ & MIDRANGE & ITEM & GROUPS & $\mathbf{N}$ & $\rho$ & MIDRANGE \\
\hline \multirow[b]{2}{*}{ I } & Salaried & 121 & \multirow[b]{2}{*}{$\begin{array}{l}0,0029 \\
(0,003)\end{array}$} & 62,69 & \multirow[b]{2}{*}{ A } & Visit & 112 & \multirow[b]{2}{*}{$\begin{array}{l}0,0026 \\
(0,008)\end{array}$} & 73,25 \\
\hline & $\begin{array}{l}\text { Employed } \\
\text { in the } \\
\text { home }\end{array}$ & 8 & & 100,00 & & $\begin{array}{c}\text { Suburban } \\
\text { farming }\end{array}$ & 25 & & 49,96 \\
\hline \multirow{2}{*}{$\mathbf{E}$} & $\begin{array}{c}\text { State } \\
\text { workers }\end{array}$ & 77 & \multirow{2}{*}{$\begin{array}{l}0,0019 \\
(0,003)\end{array}$} & 55,01 & & & & & \\
\hline & $\begin{array}{c}\text { Self- } \\
\text {-employed }\end{array}$ & 23 & & 35,39 & & & & & \\
\hline \multicolumn{5}{|c|}{$\begin{array}{l}\text { Note: You can see the meaning of Now I know, Still don't know, } \\
\text { Visit and Suburban farming in Figure } 2 \text {. In turn, } \varrho \text { is the p-value for } \\
\text { the contrast (in parenthesis, the level of risk ( } \alpha \text { ) taken after applica- } \\
\text { tion of Bonferroni correction). }\end{array}$} & & & & & \\
\hline
\end{tabular}

Source: own elaboration.

A good way to illustrate the above results is using the corresponding box plots (Figure 3).

Figure 3: Box plots of the significant cases when applying the Mann-Whitney U-test

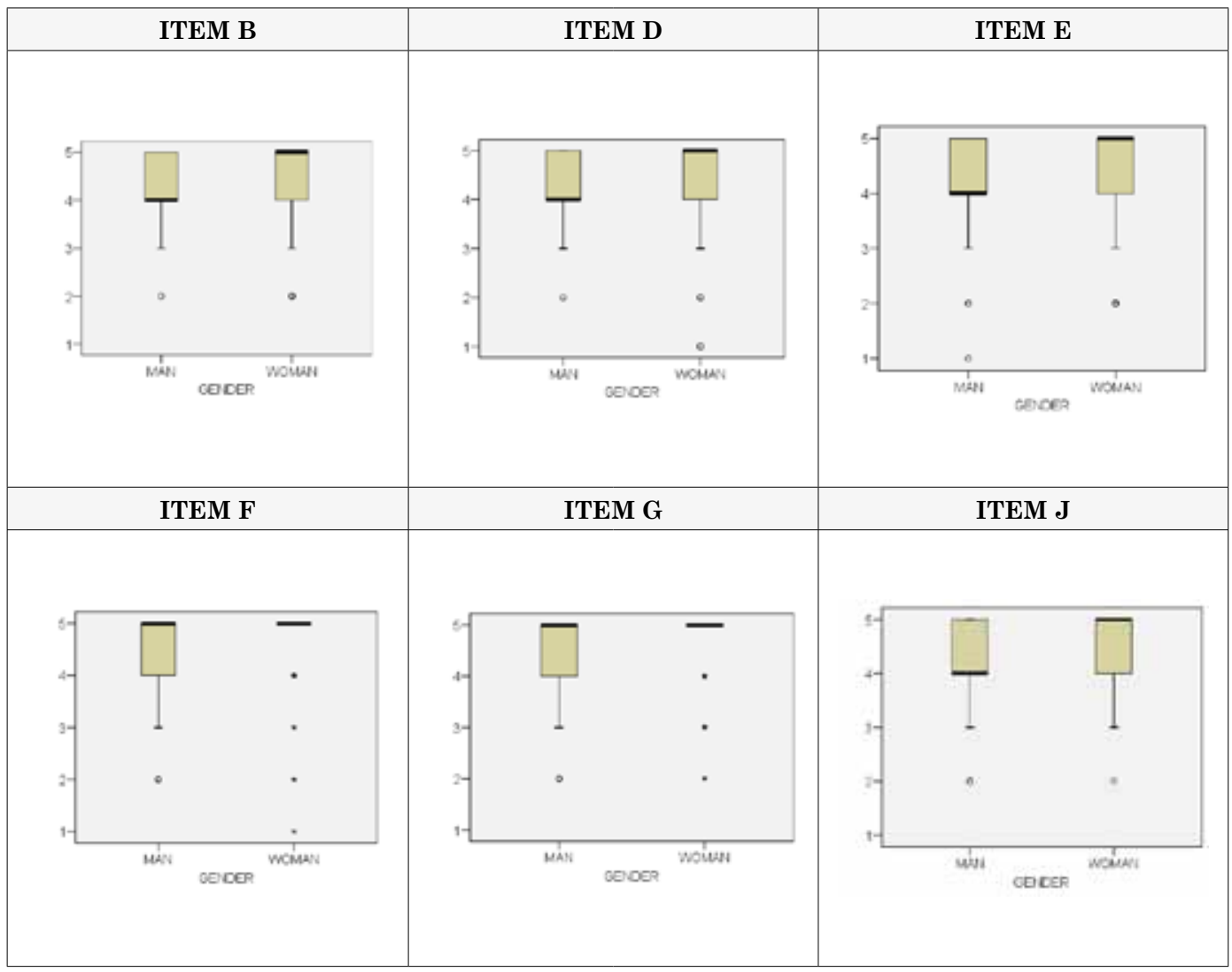




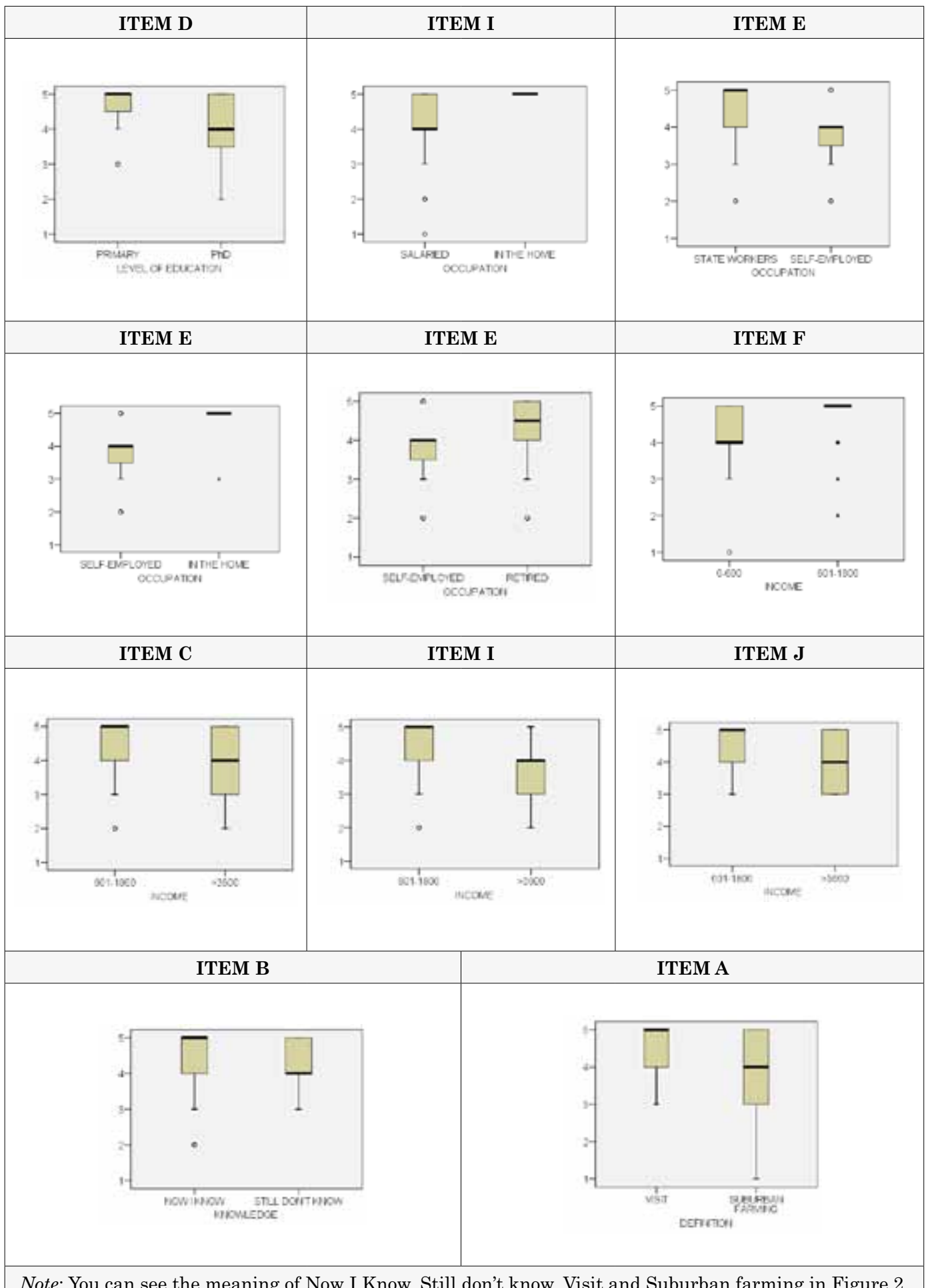

Source: own elaboration. 
As can be seen in Figure 3, in most cases the median value enables us to distinguish the group with the highest assessment scores, independent of how similar or distinct the distribution functions of both groups are. However, in the case of items $\mathrm{F}$ and $\mathrm{G}$, the median value of the appraisals made by men and women is the same, which makes it necessary to turn to their respective distribution functions to verify whether the appraisals of the women are higher.

In short, the tests undertaken reveal the following results:

The assessment of the route and its activities as a function of the sex of the interviewees: the U-test shows that, in the case of items B, D, E, F, G and J, significant differences occur between the respective assessments made by men and women. For the six items the women's evaluations are always more positive. In other words, the women hold a more favourable opinion than the men regarding their interest for all the activities offered, on the guided walk through the fields, on the guided visit to the exhibition, of the artichoke tasting, of the meeting with the farmer and regarding the adequacy of the number of people on the tour.

The assessment of the route and its activities as a function of the age of the interviewees: the $\mathrm{H}$-test shows that were no significant differences between the appraisals made by the different age groups for any of the items. It seems, therefore, that the assessment of the route and its activities is not conditioned by the age of the participants.

The assessment of the route and its activities as a function of the level of education of the interviewees: the $\mathrm{H}$-test shows that, in the case of item $\mathrm{D}$, the appraisals are significantly different between two or more groups defined on the basis of the interviewees' level of education. The U-test shows that these differences occur, exclusively, between individuals with primary studies and those that hold a PhD. Specifically, the group with the lowest level of education holds a more favourable opinion of the guided walk through the fields than the more highly qualified group.

The assessment of the route and its activities as a function of the occupation of the interviewees: the $\mathrm{H}$-test shows that, in the case of items $\mathrm{E}$ and $\mathrm{I}$, the appraisals are significantly different between two or more groups defined on the basis of the occupation of the interviewees. The U-test shows that, in the case of item E, those that work in the state sector, those that are employed in the home and those that are retired make statistically more positive appraisals than the self-employed. Likewise, in the case of item I, the same test shows that those employed in the home make significantly more positive appraisals than those that work as salaried employees. In short, the guided visit to the exhibition is enjoyed less by the self-employed than it is by state workers, those that are employed in the home and the retired; while the pacing and rhythm of the activities is more highly appraised by those employed in the home than it is by those that work as salaried employees.

The assessment of the route and its activities as a function of the monthly family income of the interviewees: the $\mathrm{H}$-test shows that, in the case of items C, F, I and J, the assessments differ significantly between two or more groups defined on the basis of the monthly family income of the interviewees. The U-test shows that individuals in the group with the second lowest income $(601-1,800)$ make statistically more positive appraisals than those in the group with the lowest income (0-600), in the case of item F, and than those in the group with the highest income $(>3,600)$, in the case of items $\mathrm{C}, \mathrm{I}$ and J. In other words, in the two groups of lowest income levels, the individuals with a family income below 600 euros did not enjoy the artichoke tasting as much. Moreover, the individuals in the group with the second lowest income level enjoyed the explanations more and appreciated the pacing and rhythm of the activities more, considering the number of participants to be more correct than was the case of those with the highest levels of income.

The assessment of the route and its activities as a function of the participants' knowledge of vegetable tourism: the $H$-test shows that, in the case of item $B$, the assessments differ significantly between two or more groups defined on the basis of their responses to the question: Do you know what vegetable tourism is? The U-test shows that these differences occur, exclusively, between those that respond: "I'd never heard of it until I started the route, but now I know what it means because it has been explained to me" and those that answer: "I have heard of it, but I still do not know what it means". Specifically, the first group offers more positive appraisals. In other words, those that declare that they have discovered the meaning of vegetable tourism during their visit report more favourable impressions of all the activities than those reported by individuals who, even after the visit, still do not know what vegetable tourism is.

The assessment of the route and its activities as a function of the definition given of vegetable tourism: the $H$-test shows that, in the case of item $A$, the assessments differ significantly between two or more groups defined on the basis of their response to the question: How would you 
define vegetable tourism? The U-test shows that these differences occur, exclusively, between those that respond: "visits to a suburban farming area in the outskirts of a city" and those that answer: "suburban farming", with the former reporting more positive appraisals. Therefore, the respondents that hold a basically acceptable definition of vegetable tourism have a more favourable opinion regarding the sufficiency of the number of activities programmed than those who hold an erroneous definition.

\section{Discussion and conclusions}

Among the many new trends observed in the tourism sector, the one that stands out most is perhaps the emergence of a new type of tourist, with their own set of highly individualised tastes and expectations that are increasingly oriented towards a so-called experiential consumption (Pine and Gilmore, 1999). This new tendency represents a considerable challenge for an established power of the tourist sector such as Spain, which is suffering a reduction in the profitability of its traditional sun and beach tourist product due, among other factors, to direct competition from other Mediterranean destinations (Kozak and Martin, 2012). As a result, and as is emphasised in Spain's Tourism Plan Horizon 2020 (SGT, 2007), one of the main current lines of action involves the innovative design of a new range of tourist products. These adhere to a strategy of market segmentation that permits the development of proposals that are better adapted to the new requirements of the market and which promote deseasonalisation and a more equitable socio-territorial balance of tourist flows.

Among the various alternatives proposed special mention should be made, given the direct involvement of the tourist and the consequent emanation of their emotions and sensations, of the tourist activity being developed on working farms and within the sector of agritourism (Phillip et al., 2010). Aimed at satisfying the increasing experiential needs of tourists, agritourism has evolved, giving rise to the appearance of a range of innovative variants. Among these we find vegetable tourism, or what amounts to the same thing, a sector aimed at discovering market gardens and orchards, and which has been the focus of this paper.

The existence of this unique and innovative activity in Spain, specifically in the Parc Agrari del Baix Llobregat, represents an excellent opportunity to obtain information first hand about a type of tourism that may well establish itself as an attractive alternative for certain areas specialising in the production of vegetable crops in peri-urban environments. These include the market gardens of Valencia and Murcia (Meeus, 1995), and the zones of intensive production of horticultural crops along the coast of Andalusia (Molinero et al., 2011). In contrast with the typical approach adopted in analyses of agritourism projects, this article has considered it more interesting to focus on the demand factor in this sector.

The results obtained show that the average profile of the person who enjoys activities related to vegetable tourism is that of a woman, fairly advanced in years, with a university degree, working as a salaried employee and with a medium-high purchasing power. Likewise, the evidence obtained shows that the explanations received by the visitors while on the agritourist route help improve their understanding of the concept of vegetable tourism.

Furthermore, it is apparent that those who participate in vegetable tourism activities are very satisfied with the route, as is reflected in the high assessment scores awarded to each of the activities included on it. These results seem to confirm the thesis of such authors as Carpenter et al. (1994), according to which consumers show a more favourable predisposition to a new product.

In general, the opinions of the women interviewed tend to be more positive than those of the men, while the age of the visitors does not have a significant influence on their appraisals. Interestingly, certain aspects of the route receive a poorer assessment from individuals with a higher income than they do from those classified in a medium-low level income group. Thus, the study is able to contribute new evidence regarding the influence of socio-demographic variables on the tourists' appraisals of the destinations they visit, compared to previous contributions (Beerli and Martin, 2004; Craggs and Schofield, 2011).

Yet, undoubtedly, what is most significant is that the interest expressed by those visitors who believe they understand the concept of vegetable tourism thanks to the explanations offered on the tour is significantly higher for all the route's activities than it is among those who, following the visit, remain unsure as to what the sector actually is. Likewise, the number of activities programmed is considered to be more appropriate as the visitors' knowledge of vegetable tourism improves. These results are largely in line with those obtained by Zhou and Nakamoto (2007), who verify that it is the consumers that are most familiar with a product that tend to offer better assessments of it. 
In short, the evidence suggests that novel experiences such as the one analysed here can be highly attractive, above all if the operators are successful in ensuring that users understand the exact nature of their offer. However, if the design and management of such alternative proposals are to be improved, it is essential to conduct in-depth analyses of the demand, with the aim, among others, of identifying the specific segments of tourists that might be attracted by it and of determining the fundamental characteristics of their profile.

\section{Acknowledgements}

This paper has been prepared as part of the project CSO2009-12225-C05-03, funded by the Spanish Ministry of Science and Innovation.

\section{End notes}

1. This is confirmed by comparing the z-scores for kurtosis and skewness with the critical region $(\mathrm{a}=$ 0.05) obtained from the normal distribution and the application of the Kolmogorov-Smirnov one-sample test $(\mathrm{a}=0.05)$.

2. To avoid Type I error, we use the Bonferroni correction, which involves dividing the level of risk $(\mathrm{a}=0.05)$ by the number of comparisons made $(\mathrm{k})$, which depends on the number of groups $(\mathrm{n})$ in which the variable under consideration has been divided $(\mathrm{k}=\mathrm{n}(\mathrm{n}-1) / 2)$.

\section{References}

Alba J W, Hutchinson, J W.

1987. "Dimensions of consumer expertise". Journal of Consumer Research, 13(4): 411-454.

Arnberger A, Brandenburg C.

2007. "Past On-Site Experience, Crowding Perceptions and Use Displacement of Visitor Groups to a

Peri-Urban National Park". Environmental Management, 40: 34-45.

Beerli A, Martín J D.

2004. "Tourists' characteristics and the perceived image of tourist destinations: a quantitative analysis-a case study of Lanzarote, Spain”. Tourism Management, 25(5): 623-636.

Bowen R L, Cox L, Fox M.

1991. "The interface between tourism and agriculture". Journal of Tourism Studies, 2(2): 43-54.

Brady M K, Robertson C J, Cronin J J.

2001. "Managing behavioral intentions in diverse cultural environments: an investigation of service quality, service value, and satisfaction for American and Ecuadorian fast-food customers". Journal of International Management, 2(7): 129-149.

Bryant C R, Johnston T R R.

1992. Agriculture in the City's Countryside. University of Toronto Press: Toronto.

Bryant C R, Russwurm L H, Mclellan A G.

1982. The City's Countryside. Land and Its Management in the Rural-urban Fringe. Longman: London/ New York.

Carpenter G S, Glazer R, Nakamoto K.

1994. "Meaningful brands from meaningless differentiation: The dependence on irrelevant attributes". Journal of Marketing Research, 3(31): 339-350.

Craggs R, Schofield P.

2011. "The quays in Salford: an analysis of visitor perceptions, satisfaction and behavioural intention". International Journal of Tourism Research, 6(13): 583-599.

Cronin J J, Brady M K, Hult G T.

2000. "Assessing the effects of quality, value, and customer satisfaction on consumer behavioral intentions in service environments". Journal of Retailing, 2(76): 193-218.

Dubé-Rioux L.

1990. "The power of affective reports in predicting satisfaction judgments". Advances in Consumer Research, 17: 571-576. 
Frank R E, Massy W F, Wind Y.

1972. Market segmentation. Prentice-Hall: Englewood Cliffs, NJ

Frater J M.

1983. "Farm tourism in England. Planning, funding, promotion and some lessons from Europe". Tourism Management, 3(4): 167-79.

Frochot I.

2005. "A benefit segmentation of tourists in rural areas: a Scottish perspective". Tourism Management, 3(26): 335-346.

Hernando Riveros S, Marvin Blanco M.

2003. "El agroturismo, una alternativa para revalorizar la agroindustria local como mecanismo de desarrollo local". http://www.infoagro.net/shared/docs/a5/ACF2DB6.pdf (accessed 16 April 2009).

Hilchey D.

1993. Agritourism in New York State: opportunities and challenges in farm-based recreation and hospitality. Department of Rural Sociology, University Ithaca: New York.

Hoyland I

1982. "The development of Farm Tourism in the UK and Europe: Some Management and Economics Aspects". Farm Management, 10(4): 383-389.

Jun S, Hyun Y L, Gentry J W, Song C.

2001. "The relative influence of affective experience on consumer satisfaction under positive versus negative discrepancies". Journal of Consumer Satisfaction, Dissatisfaction and Complaining Behavior, 14: 141-153.

Kastenholz E, Davis D, Paul G.

1999. "Segmenting Tourism in Rural Areas: The Case of North and Central Portugal". Journal of Travel Research, 4(37): 353-363.

Kozak M, Martin.

2012. "Tourism life cycle and sustainability analysis: Profit-focused strategies for mature destinations". Tourism Management, 1(33):1 88-194.

Li X, Meng F, Uysal M, Mihalik B.

2011. "Understanding China's long-haul outbound travel market: An overlapped segmentation approach". Journal of Business Research, In Press, Corrected Proof, Available online 19 October 2011.

Meeus J H A.

1995. "Pan-European landscapes". Landscape and Urban Planning, 1-3(31): 57-79.

Mesa M.

2000. El turismo rural y el desarrollo local, in V Pérez, E Carrillo, Desarrollo local: manual del uso. Federación Andaluza de Municipios y Provincias y Editorial ESIC: Madrid: 556-600.

Michelyn Y, Aznar O, Guerreira F, Ménadier L, Planchat C, Vollet D.

2007. The Saint-Nectaire cheese landscapes: myth or reality?, in B Pedroli (Ed.), Europe's living landscapes. Essays exploring our identity in the countryside. KNNV Publishing: Zeist: 48-64.

Molera L, Albaladejo I P.

2007. "Profiling segments of tourists in rural areas of South-Eastern Spain". Tourism Management, 3(28): 757-767.

Molinero F, Ojeda J F, Tort J Eds.

2011. Los paisajes agrarios de España. Caracterización, evolución y tipificación. Ministerio de Medio Ambiente y Medio Rural y Marino: Madrid.

Murphy P E.

1985. Tourism: A Community Approach. Methuen: New York.

Oh J Y J, Schuett M A.

2010. "Exploring expenditure-based segmentation for rural tourism: overnight stay visitors versus excursionists to fee-fishing sites". Journal of Travel \& Tourism Marketing, 1(27): 31-50.

Oliver R L.

1981. "Measurement and Evaluation of Satisfaction Processes in Retail Settings". Journal of Retailing, 1(57): 25-48.

Oliver R L.

1999. "Whence Consumer Loyalty". Journal of Marketing, 63, Special Issue: 33-44.

Park D-B, Yoon Y-S.

2009. "Segmentation by motivation in rural tourism: A Korean case study". Tourism Management, 1(30): 99-108. 
Paül V, Araújo N.

2012. "Agroturismo en entornos periurbanos: enseñanzas de la iniciativa holeriturismo en el Parc Agrari del Baix Llobregat (Cataluña)". Cuadernos de Turismo, 29: 183-208.

Pearce P L.

1990. "Farm Tourism in New Zeland. A social situation analysis". Annals of Tourism Research, 17: 337-352. Phillip S, Hunter C, Blackstock K.

2010. “A typology for defining agritourism”. Tourism Management, 6(31): 754-758.

Pine B J, Gilmore J H.

1999. The experience economy. Harvard Business School Press: Boston.

Przezbórska L.

2003. Relationships between rural tourism and agrarian restructuring in a transitional economy: The case of Poland, en D Hall, L Roberts, M Mitchell Eds. New Directions in Rural Tourism. Ashgate: Aldershot: 203-222.

Radder L, Han X.

2011. "Segmenting And Profiling South African Minibus Taxi Commuters: A Factor-Cluster-Tabulation Analysis Approach”. International Business \& Economics Research Journal, 12(10): 127-138.

Secretaría General de Turismo (SGT)

2007. Plan del Turismo Español Horizonte 2020. Documento Ejecutivo. Ministerio de Industria, Turismo y Comercio: Madrid.

Sheskin D J.

2007. Handbook of Parametric and Nonparametric Statistical Procedures (Fourth Edition), Chapman \& Hall/CRC: Boca Ratón (Florida).

Smith W R.

1956. "Product differentiation and Market Segmentation as Alternative Marketing Strategies". Journal of Marketing, 1(21): 3-8.

Van Dolen W, De Ruytter K, Lemmink J.

2004. "An empirical assessment of the influence of customer emotions and contact employee performance on encounter and relationship satisfaction". Journal of Business Research, 5(57): 437-444.

Vanhamme J.

2000. "The Link Between Surprise and Satisfaction: An Exploratory Research on how best to Measure Surprise". Journal of Marketing Management, 6(16): 565-582.

Viñals M J.

1999. Los espacios naturales y rurales. Los nuevos escenarios de turismo sostenible, en M J Viñals, A Bernabé Eds. Turismo en espacios naturales y rurales. Universitat Politècnica de València: València: 13-33.

Zhou K Z, Nakamoto K.

2007. "How do enhanced and unique features affect new product preference? The moderating role of product familiarity”. Journal of the Academy of Marketing Science, 1(35):53-62. 